\title{
Critical Thinking in ELT: Theory and Practice
}

\author{
Lulus Irawati \\ PBI FPBS, IKIP PGRI Madiun
}

\begin{abstract}
Critical thinking may be considered as an essential substance contributing to the success of students learning a language, in this English. Some skills in English such as listening, speaking, reading and writing can be successfully achieved whenever students were critical, since critical thinking is also the ability allowing the students to express everything freely. Unfortunately, utilizing critical thinking is not as simple as seen. There should be a regular and consistent process done to encourage the students to be critical. Thus, some approaches, methods, techniques or media need to be applied in order to succeed the achievement of being critical thinkers. Thus, this paper reveals some theories and practices based on reviewing some articles of critical thinking in English Language Teaching (ELT).
\end{abstract}

\section{INTRODUCTION}

Critical thinking has become prominent educational issue in many Asia countries recently. It is believed that critical thinking is important to be included as one of skills hand in hand with learning a foreign language, in this case English. It means that critical thinking is also necessarily taught to the students merging with learning English language skills namely listening, speaking, reading, and writing, although this is not going to be easy. Accordingly, critical thinking is cognitive process in which the students are emerged to use their minds to observe, think, categorize, and hypothesize (William and Burden, 1997). Therefore, it is not one-shot treatment, but it is a long journey treatment to make the students become critical or more critical and more independent.

In Western countries, emerging critical thinking has been significantly started from elementary level up to tertiary level of education. Many kinds of tasks and activities done inside or outside the classroom are truly organized with the purpose to make the students observe, think, categorize and hypothesize. That is why critical thinking has not popularly taken to be a discussion or theme in the education based research. In contrast, most countries in Asia still considers critical thinking as a challenging and promising topic in the education based research. Some research show that most Asian learners have not been critical yet or only less critical. In fact, this can be related with the culture of Asian learners who always believes that 'silence is gold' or 'being quiet is good'. As a result, the students or learners 
tend to be quiet, passive, and obedient in order to give good impression to their teacher that they are polite. It is also supported by Liaw (2007) that in Taiwan, student-teacher interaction is either lacking or inadequate and the English language instruction is far from being conducive to fostering critical thinking.

Due to the facts above, putting critical thinking into practice is urgently needed for EFL learners. This certainly become the responsibility of EFL teachers to train their students acquiring or developing critical thinking while learning English. Without comprehensive practice in critical thinking, the students can miss the chance to be more independent and highly self-confident people who actively participate in the global workplace and international community. Therefore, teaching critical thinking intentionally is the best way of the solution offered here. Legally, critical thinking is necessarily emerged into the curriculum starting from elementary level to tertiary level of education. By doing so, teaching critical thinking is a must conducted inside the classroom, since some objectives and indicators have been provided in the curriculum. The teachers only need to select appropriate teaching approaches, methods or techniques.

\section{CRITICAL THINKING}

Critical thinking, as defined in the previous study, is a globally-disseminated educational ideal for preparing students in a knowledge-based economy, where information and technology leads the world to drastically shrink (Jantrasakul, 2004). It is clearly shown that critical thinking can be not only used to teach a language but also other subjects, such as social science. Moreover, Jantrasakul (2004) and Errihani (2012) also suggests that there are two approaches postulated by Atkinson in term of making the understanding of critical thinking namely critical thinking as a social practice which is more social-cultural practice and as a social justice which is asked the students and the teacher to actively engage in learning. Meanwhile, Liaw (2007) believed that critical thinking is an ongoing process in which all language learners must engage, regardless of their language proficiency levels. Based on the statement, it can be concluded that the teacher needs to provide a proper process in order to raise the students' critical thinking. The process can include making inferences, questions, and solving problems.

Due to the process provided to raise students' critical thinking, some researchers that they reported in their research-based articles have chosen a model developed by Anderson, Krathwohl, and Bloom. The model included knowledge, comprehension, inference, 
application, analysis, synthesis, and evaluation (Khatib \& Alizadeh, 2012; Hosseini et al, 2012; Wang, 2009). In contrast, some reseachers did not propose a critical thinking model clearly. They only stressed the importance of involving students in the process of thinking (Mok, 2009) and assigned or investigated the students the ability to analyze and evaluate the different texts that were given by the teacher (Liaw, 2007; Tung and Chang, 2009). Thus, Ghanizadeh and Mirzaee (2012) thought that learning to think critically is one of the key objectives of formal education. Interestingly, bringing the idea of critical thinking into the English language learning is not something easy that we, as the researchers need to set up the operational definition in order to make everything very clear in the beginning and the model proposed by some researcher above should not become an end-way, but an applicable-way.

\section{TEACHING CRITICAL THINKING}

To make critical thinking to be more realistic and measurable, critical thinking needs to be taught comprehensively in every level of education, in this case for EFL learners. Learning a foreign language like English will be more interesting while the teacher is not only being the center of classroom, but also giving more spaces for the students to be the center of classroom by providing them something that can stimulate them to analyze, evaluate, explain and many more. In this respect, the teacher does not feed the students all the time, but she/he provides a problem or a task to be solved. Unfortunately, there are only few research-based articles explaining how to teach critical thinking clearly.

Some researchers, as stated in the previous section above, only proposed a critical thinking model consisting of knowledge, comprehension, inference, application, analysis, synthesis, and evaluation or only investigated wether the abilty to analyze, evaluate, comprehend occur that sound not applicable (Hosseini et al, 2012; Wang, 2009; Tung and Chang, 2009; Ghanizadeh and Mirzaee, 2012; Brumfit et.al, 2005; Mok, 2009). They directly use materials and media such literary texts or passages, movies, and pictures to check students' critical thinking. They did not propose some procedure or steps to teach and develop critical thinking.

Surprisingly, Khatib and Alizadeh (2012) thought that critical thinking is an indispensible part of teaching every subject, which is crucial for learners to master it. That is why Khatib and Alizadeh proposed the model by Jun Xu (2011). The model includes five steps as follows: 
1. First step : Pre-reading-Introducing background or cultural knowledge to students.

2. Second step : comprehending of the text and explicating the main idea of each paragraph.

3. Third step : analyzing the logic of the text.

4. Fourth step : evaluating the logic of the text.

5. Fifth step : Writing.

It is obviously shown that the steps above are not only used to check the students' development of critical thinking, but also used significantly to apply inside the classroom.

Meanwhile, another researcher like Liaw (2007) utilized content-based approach to make teaching critical thinking more realistic. The design of critical thinking tasks for the students incorporated: (1) selection of tasks from different levels of the cognitive domain, (2) prior knowledge and experience of the students whenever possible, (3) contextualization of the task with activities and graphic organizers for reading and writing, (4) awareness of language complexity when asking students questions or providing directions, and (5) frequent assessment of the students' progress. It can be seen that content is used to a meaningful context for developing students' language skills and critical thinking skill.

\section{ASSESSING CRITICAL THINKING}

Assessment is one of important parts in the teaching and learning process. All activities done inside the classroom need to be assessed in order to see whether the activities can improve students' understanding and change their behavior. There are two kinds of classroom-related domain of assessment: (a) teacher-design formal tests that refer to a product; (b) informal assessment in the context of day-by-day interaction with students that refers to a process (Brown, 2001). Based on the statement above, it can be postulated that assessment is needed hand in hand right after conducting teaching and learning process whether it is an informal or formal assessment.

In line with the fact above, proposing an assessment on critical thinking is extremely important, since teaching critical thinking has been done by some researchers. Most researchers proposed formal assessment, Critical Thinking Skill Tests that provided many versions namely the California Critical Thinking Skill Tests (CCTST) and the Watson-Glaser Critical Thinking Appraisal (WGCTA). The CCTST is a standardized test comprising 34 multiple-choice questions. It measures an individual's overall critical thinking ability and his/her critical thinking skills in analysis, evaluation, inference, deductive reasoning and 
inductive reasoning. Tung and Chang (2009) took the CCTST of Chinese version to avoid any confusion or ambiguity in meanings that may incur due to language problem. Meanwhile, Hosseini, et.al(2012) took the CCTST of Persian version, form B to determine participants' critical thinking. Other researchers took the WGCTA (Ghanizadeh \& Mirzaee, 2012; Khatib \& Alizadeh, 2012; Hosseini, et. al, 2012). This test comprises 80 items and consists of 5 subtests as follows:

\begin{tabular}{|l|l|}
\hline Subtest & Description \\
\hline Test 1. Inference & $\begin{array}{l}\text { Discriminating among degrees of truth or } \\
\text { falsity of inference drawn from given data. }\end{array}$ \\
\hline Test 2. Recognizing Unstated Assumptions & $\begin{array}{l}\text { Recognizing unstated assumptions or } \\
\text { presuppositions in given statements or } \\
\text { assertions. }\end{array}$ \\
\hline Test 3. Deduction & $\begin{array}{l}\text { Determining whether certain conclusions } \\
\text { necessarily follow from information in } \\
\text { given statement or premises. }\end{array}$ \\
\hline Test 4. Interpretation & $\begin{array}{l}\text { Weighing evidence and deciding if } \\
\text { generalizations or conclusions based on the } \\
\text { given data are warranted. }\end{array}$ \\
\hline Test 5. Evaluation of Arguments & $\begin{array}{l}\text { Evaluation of Arguments: Distinguishing } \\
\text { between arguments that are strong and } \\
\text { relevant and those that are weak or relevant } \\
\text { to a particular question at issue. }\end{array}$ \\
\hline
\end{tabular}

As stated above, the tests proposed by some researchers here can certainly help to assess students' critical thinking. Unfortunately, the researchers did not pay much attention on how the students achieve the critical thinking skill as served in the table. They also did not select materials carefully due to achieving the skill. Therefore, they only focused on the product or tried to check students' critical thinking skill. In fact, good assessment should keep balance with the treatment or the process done inside the classroom in order to provide fair results for the students.

In contrast, there are also some researchers who proposed their own made assessment on critical thinking and it designed in line with the process done inside the classroom. They also provided some related materials that can be significantly seen to achieve the sets of critical thinking. For example, some critical questions like 'what moral can you get from the story?' or what messages can you derive from the story' were raised based on the passages or texts (Brumfit, 2005; Liaw, 2007). They take some materials not only from then textbooks but also from other source in order to represent every single critical thinking skill (Mok, 2009; Wang, 2009; Jantrasakul, 2012). Thus, it is really shown that as teachers, we need to consider not only a product assessment but also a process assessment. Certainly, the process 
assessment need to be conducted in the very beginning before the product assessment. It would give a fair chance for the students in being assessed.

\section{IMPLICATIONS OF CRITICAL THINKING IN ELT}

Due to the facts above, critical thinking discussed here should not be applied alone without merging with other skills or subjects. That is why this section is going to discuss what implications of critical thinking in ELT in which the implications relate to the four English skills: listening, speaking, reading and writing. Among four skills above, the listening is the most neglectful, since most researchers were only interested in merging critical thinking with reading classified at the first position. Then, it was followed by writing and speaking.

For most researchers, they could easily choose the reading passages or texts, which were showing the complexity of content, then they directly assigned the students to read, after that, they provided some questions to answer, and finally, they could give critical thinking test to measure whether there was a difference. In merging with writing, the researcher needed more detail and careful attention, since writing itself is a process skill that somehow, might have been the same as critical thinking. They provided the topics that could challenge students' way of thinking. The topics chosen usually were used to stimulate the students from the activities reflecting knowledge, comprehension, inference, application, analysis, synthesis to evaluation. Therefore, the students had to give enough time to search and explore information from many sources in order to easily generate ideas before writing. While in speaking, it was not clearly shown, since speaking is a kind of productive skill, the same as writing. It can be sometimes merged in time of writing or reading activities. The students may directly explain what they have written or retell what they have read.

Interestingly, media also play an important role to support students being more critical in thinking. The media used were pictures inside the children story books such as 'the fox and the crow', 'the sleeping beauty' and many more. The students may relate the pictures provided with the story is about. To make more challenging, the teacher can provide only a series of picture taken from the storybook and then ask the students to construct some sentences based on the series of pictures. This media certainly are suitable for junior high school students rather than higher-level students. At last, critical thinking is necessary to be applied from low level of education to high level of education merging with certain subject taught at school, in this case English. The younger the students are trained for critical thinking, the better they can achieve in their future. 


\section{CONCLUSION}

Due to the explanation above, we, as teachers get much information what critical thinking is, how critical thinking is applied merging with the English skills, how critical thinking is assessed. It is also shown that critical thinking is not something impossible to be applied inside the classroom as long as the teacher does all sets of critical thinking such as knowledge, comprehension, inference, application, analysis, synthesis to evaluation properly. The teacher has to choose suitable materials, technique, method or media to be applied inside the classroom, and then she or he can assess the students with suitable assessment either adopting from the existing critical thinking tests or creating their own made critical thinking tests.

\section{REFERENCES}

Brumfit, Christopher, et.al.2005. Language study in higher education and the development of criticality. International Journal of Applied Linguistics, Vol. 15, No 12.

Errihani, Mohammed. 2012. Critical Thinking and the Language Factor: The case for the English Language Learner. AWEJ, Vol 3 No. 3.

Ghanizadeh, Afsaneh and Mirzaee, Sepideh. 2012. EFL Learners' Self-regulation, Critical Thinking and Language Achievement. International Journal of Linguistics, Vol. 4, No.3

Hosseini, Effat, et.al. 2012. Exploring the Relationship between Critical Thinking, Reading Comprehension and Reading Strategies of English University Students. World Applied Sciences Journal, 17 (10).

Jantrasakul, Prapai. 2012. Utilizing Critical Thinking-based EFL lessons: A means to improve language skills and encourage student engagement in Thai EFL classes. Journal of Education and Practice, Vol. 3, No. 6.

Khatib, Mohammad and Alizadeh, Iman. 2012. Critical Thinking Skills through Literary and Non-literary Texts in English Classes. International Journal of Linguistics, Vol. 4, No.4.

Liaw, Meei-Ling. 2007. Content-based Reading and Writing for Critical Thinking Skills in an EFL Context. English Teaching and Learning, 31.2 (Summer 2007).

Mok, Jane. 2009. From Policies to Realities: Developing Students' Critical Thinking in Hongkong Secondary School English Writing Classes. RELC, Vol. 40(3).

Tung, Chi-An and Chang, Shu-Ying. 2009. Developing Critical Thinking through Literature Reading. Feng Chia Journal of Humanities and Social Sciences, pp. 287-317, No. 19 
Wang, Ya-huei. 2009. Incorporating Critical Thinking Skills into an English Conversation Program. European Journal of Social Sciences, Vol. 11, No. 1.

Williams, Marion and Burden, Robert L. 1997. Psychology for Language Teachers: A Social constructivist approach. UK: Cambridge University Press. 